\title{
Structure, Core Losses, Curie Temperature, Defects in the Structure of the Bulk Amorphous Alloy $\mathrm{Fe}_{55} \mathrm{Co}_{15} \mathrm{~W}_{2} \mathrm{Y}_{8} \mathrm{~B}_{20}$
}

\begin{abstract}
JOANNA GONDRO*
Institute of Physics, Faculty of Production Engineering and Materials Technology, Czestochowa University of Technology, 19 Armii Krajowej Str., 42-200 Czestochowa, Poland

This paper presents studies relating to the structure and soft magnetic properties of the bulk amorphous alloys $\mathrm{Fe}_{55} \mathrm{CO}_{15} \mathrm{~W}_{2} \mathrm{Y}_{8} \mathrm{~B}_{20}$. Samples were made using the method of injecting a liquid alloy into a copper watercooled mold in the form of plates. The structure and microstructure were examined using $X$-ray diffractometry. Magnetic properties were investigated from static and dynamic measurements. For the samples, the core losses were measured. The influence of structure defects on the magnetization process in strong magnetic fields was also investigated. For this purpose, the theory developed by $\mathrm{H}$. Kronmüller was used. It was shown that the magnetization process in strong magnetic fields is associated with two-dimensional defects, so-called pseudo-location dipoles.
\end{abstract}

Keywords: bulk amorphous alloy, core losses, magnetization, temperature Curie, X-ray diffraction

Amorphous materials have been extensivelystudied for over half a century [1-8].The reason for interestin this group of materials are their unique properties, which are significantly better than for their crystalline counterparts with the same chemical compositions [9-11]. Amorphous materials divided into two groups: classic and massive [12-16]. This division accurately separates these two groups of materials depending on their thickness. Classic amorphous materials are mainly thin tapes produced using the melt spinning method [17, 18]. The boundary thickness of tapes, for some alloys is $100 \mathrm{im} \mathrm{[19].} \mathrm{It} \mathrm{has} \mathrm{been}$ assumed that amorphous materials with a thickness of more than $100 \mathrm{im}$ are called massive amorphous materials. Bulk alloys are mainly produced using two methods: suction and injection of a liquid alloyinto the copper mold [20-23]. Produced samples are generally in the form of rods or platelets less tubes. In the production of bulk amorphous alloys, the formation of appropriate shapes is very difficult due to their high brittleness [24, 25]. The bulk amorphous iron-based materials have a great brittleness [26-29].This separated group of alloys with the appropriate chemical composition may exhibit magnetic properties, so-called soft or hard [30,31]. When it comes to hard magnetic materials, it is difficult to talk about the amorphous structure and the good properties of the so-called hard. Generally, the permanent magnets is nanocrystalline materials produced by the powder components [33-34]. In contrast, soft magnetic materials can be produced as solid amorphous cores. Amorphous material has one big advantage, unlike crystalline materials, they do not have magneto-crystalline anisotropy. In addition, most of these alloys have almost zero magnetostriction. This advantage causes that these materials have no negative impact on the environment (they do not generate excessive heat and noise). In conventional ferromagnetic materials, during the re-magnetization, noise is heard and there is excessive heat release for the standard frequency at which the transformer operates [35-45]. Therefore, amorphous materials are very interesting due to their applicability in the electrotechnical industry and electronics.

The paper presents the results of investigations of structure and magnetic properties for samples of bulk amorphous alloy $\mathrm{Fe}_{55} \mathrm{Co}_{15} \mathrm{~W}_{2} \mathrm{Y}_{8} \mathrm{~B}_{20}$ in the form of a plate with a thickness of $0.5 \mathrm{~mm}$.

\section{Experimental part}

Samples for testing were made of purity elements: Fe $99.99 \%$ at, Co - 99,98\%, Y - 99.98\% at., (boron was added as a Fe ${ }_{56.4} \mathrm{~B}_{43.6}$ compound). The weighed components were melted using an electric arc at different operating currents. Homogenization of the ingotwas done in an Ar atmosphere $(0.3 \mathrm{~atm} \mathrm{Ar})$. The ingots were melted several times on both sides. Then, prepared ingots weighing $10 \mathrm{~g}$ were mechanically cleaned and in an ultrasonic cleaner. After dividing them into smaller portions, core castings were made in the form of $0.5 \mathrm{~mm}$ thick plates. These plates were made using the method of injecting a liquid alloy into a copper water-cooled mold. The injection of the liquid alloy under pressure was carried out in an Ar atmosphere. The plates obtained were initially analyzed by organoleptic studies and using optical microscopy. Selected samples were analyzed structure using X-ray diffractometer Bruker D8 Advanced. The shredded plates were irradiated with Xrays at an angle of 2 theta 30 - 120 with a time of $7 \mathrm{~s}$ per measuring step of 0.02 . The magnetic polarization of saturation as a function of temperature was measured using the Faraday magnetic balance. The measurement was performed in a vacuum in the temperature range from room temperature to $830 \mathrm{~K}$. Using the $\left(\mu_{0} \mathrm{M}_{\mathrm{s}}\right)^{1 / \mathrm{a}}$ relationship as a function of temperature, where: $\beta$ is the critical exponent appearing in the equation $\mu_{0} M_{s}=\mu_{0} M_{0}\left(1-T / T_{c}\right)^{\beta}(\beta$ $=0.36$ for Haisenberg's ferromagnetic, $\mu_{0} M_{0}$ - magnetic saturation polarization at temperature $T=0 \mathrm{~K}, \mathrm{~T}$ - Curie temperature), the Curie temperature was determined for the prepared samples in the solidified state. The losses for the re-magnetization were measured at room temperature on the FERROTESTER device in the frequency range from $50 \mathrm{~Hz}$ to $1000 \mathrm{~Hz}$. The analysis of the initial magnetization curve was made based on the theory of $\mathrm{H}$. Kronmüller called the theory of the approach to ferromagnetic saturation.

\section{Results and discussions}

Figure 1 shows the $X$-ray diffraction pattern obtained with a powdered alloy sample. 


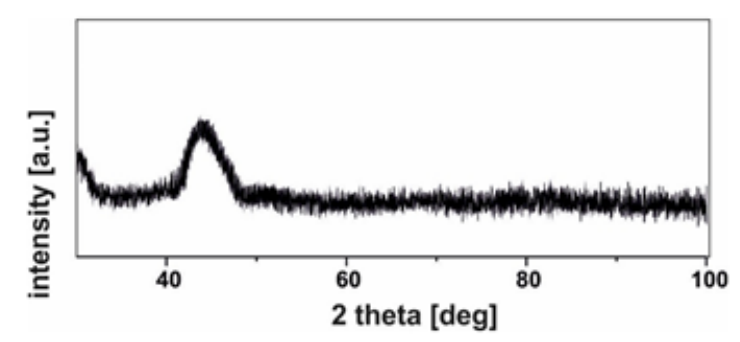

Fig. 1. X-ray diffraction patterns for the investigated alloy

The X-ray diffraction pattern consists only of a single wide maximum directly related to the amorphous structure. Lack of expressive narrow reflections of high intensity is a confirmation that the investigated material in its volume has no spatial configuration characterized by the same atom distribution while maintaining angular translations. Such material as a result of the lack of crystallites should be free of magnetocrystalline anisotropy, which has a big influence on the properties of magnetic materials. FeCoB-based alloys also exhibit low magnetostriction. Therefore, magnetic measurements are carried outfor them. In figure 2, a static magnetic hysteresis loop obtained for the tested $\mathrm{Fe}_{55} \mathrm{CO}_{15} \mathrm{~W}_{2} \mathrm{Y}_{8} \mathrm{~B}_{20}$ alloy is presented. The shape of this loop is typicall of magnetic materials exhibiting magnetically soft properties.

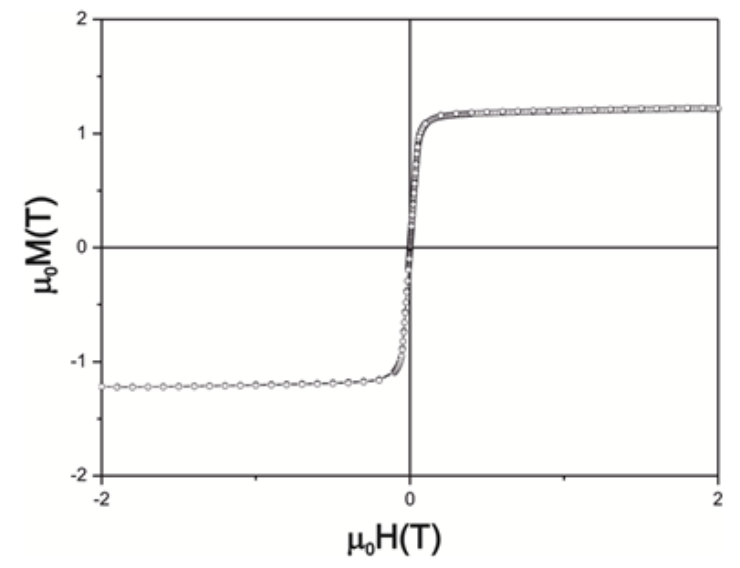

Fig. 2. Static magnetic hysteresis loop for $\mathrm{Fe}_{55} \mathrm{Co}_{15} \mathrm{~W}_{2} \mathrm{Y}_{8} \mathrm{~B}_{20}$ alloy

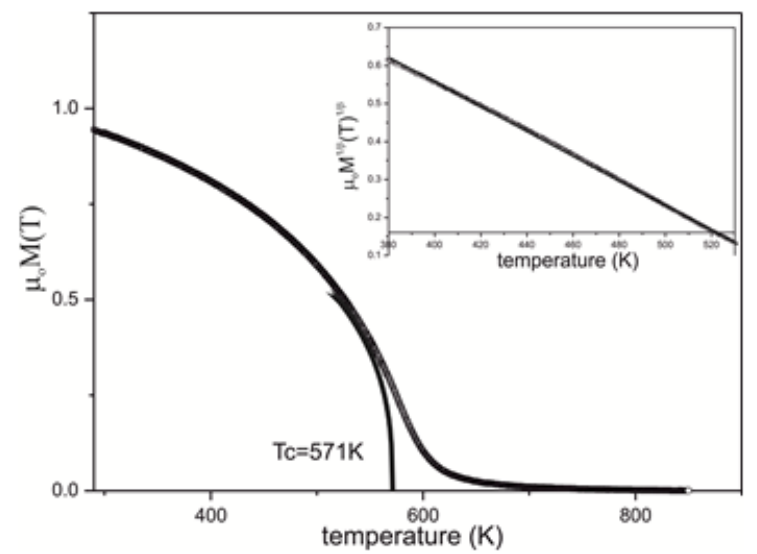

Fig. 3. Magnetization versus temperature at $B=0.75 T$ for the rods amorphous $\mathrm{Fe}_{55} \mathrm{CO}_{15} \mathrm{~W}_{2} \mathrm{Y}_{8} \mathrm{~B}_{20}$ alloy in the as-quenched state. Critical behavior of magnetization to determine the Curie points is inset

On the basis of the analysis of the static magnetic hysteresis loop, values of coercivity and saturation magnetization were determined: $38 \mathrm{~A} / \mathrm{m}, 1.22 \mathrm{~T}$ respectively. An important application parameter for soft magnetic materials is their Curie temperature value.

For the test material Curie temperature calculated according to the relation $\left(\mu_{0} \mathrm{M}_{s}\right)^{1 / \beta}$ is $571 \mathrm{~K}$. This temperature is completely sufficient for the tested material to be used as a magnetic core used in the construction of transformers. In addition, the material used for the magnetic cores of the transformer should exhibit low core losses, which can be measured by the surface of the magnetic hysteresis loop. Figure 4 shows dynamic magnetic hysteresis loops measured at frequencies from $50 \mathrm{~Hz}$ to $1000 \mathrm{~Hz}$.

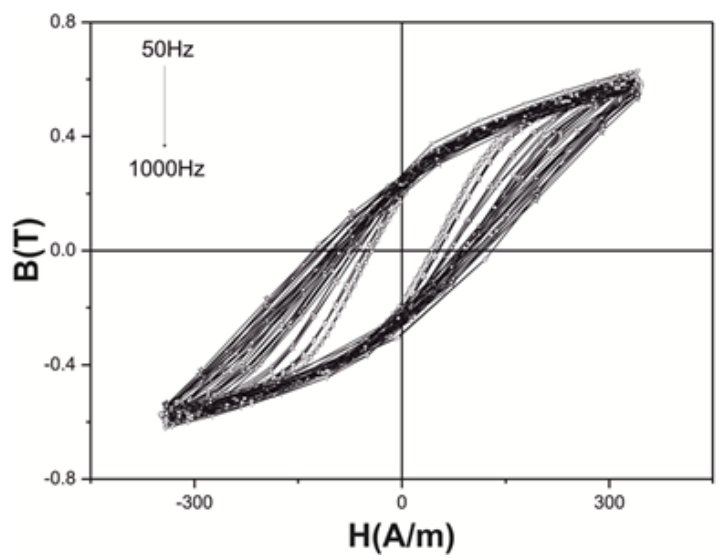

Fig. 4. Dynamic magnetic hysteresis loops measured at frequencies from $50 \mathrm{~Hz}$ to $1000 \mathrm{~Hz}$

The surface of individual hysteresis loops changes as the frequency changes. It can be seen that for higher frequencies its surface increases. This is consistent with the assumptions, that the core losses grow with the square of frequency. Figure 5 presents a graph describing the dependence of core losses on the square of frequency.

Figure 6 presents the relationships describing the core losses in the function of induction for differentfrequencies.

With increasing frequency increases the maximum magnetic induction. This behavior is typical and does not require a comment. An important magnetic parameter is the maximum magnetic permeability determining the

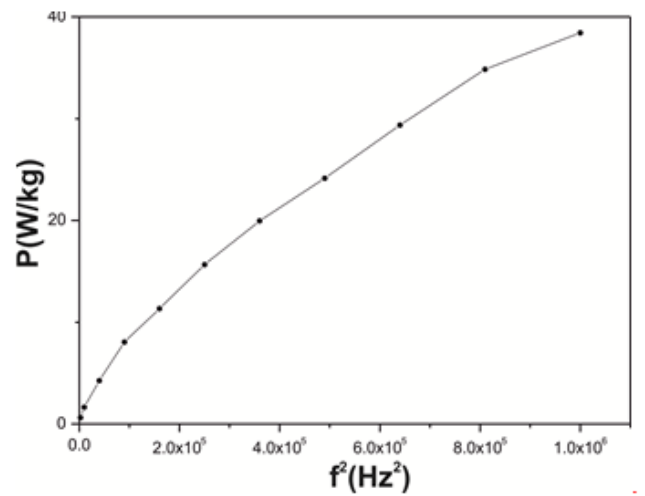

Fig. 5. Core losses in function of frequency squared

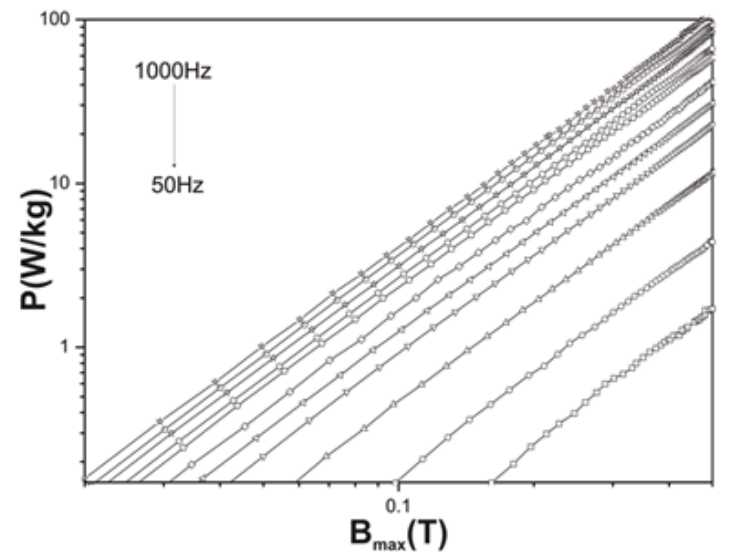

Fig. 6. The core losses in the function of induction measured at frequencies from $50 \mathrm{~Hz}$ to $1000 \mathrm{~Hz}$ 


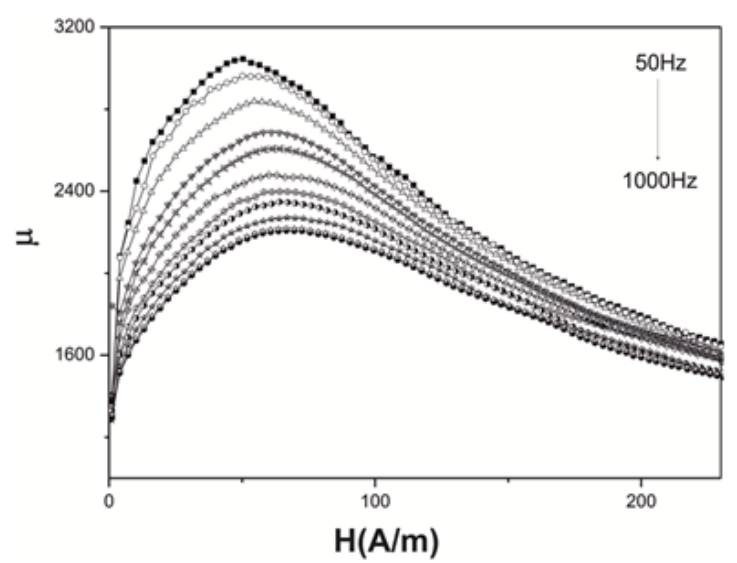

Fig. 7. The magnetic permeability as a function of magnetic field strength

ability of a given material to change the magnetic induction vector at the change of magnetic field strength. Figure 7 shows the diagrams of the dependence of magnetic permeability on the intensity of the magnetic field. On the basis of the analysis of the course of the magnetic permeability curves, it can be stated that the maximum magnetic permeability decreases with the increase of the measurement frequency. The top of the wide maximum describes the value of maximum permeability and it moves towards the higher magnetic field intensity for higher measurement frequencies.

In the case of materials for use in electrical engineering, an important and usually overlooked aspect is their good homogeneity of the structure, which contributes to a significant extent to reducing the resistances in the free flow of magnetic flux. Using the theory of $\mathrm{H}$. Kronmüller, so-called approaches to ferromagnetic saturation, one can indirectly investigate the influence of defects of the amorphous structure on the magnetization process in strong magnetic fields above the field of magnetic anisotropy. In this area there is no domain structure and the magnetizing process is associated with the presence of structural defects. As a result of the analysis of the original magnetization curve for the tested alloy, it was found that the magnetizing process in the area of the approach to ferromagnetic saturation is associated with the second law [46]. This means that in the magnetic field strength range of $0.16 \mathrm{~T}$ to $0.5 \mathrm{~T}$, the process of magnetizing the $\mathrm{Fe}_{55} \mathrm{CO}_{15} \mathrm{~W}_{2} \mathrm{Y}_{8} \mathrm{~B}_{20}$ alloy sample is related to the presence of two-dimensional defects called pseudodislocation dipoles (fig. 8).

In higher magnetic fields from $0.5 \mathrm{~T}$, the magnetizing process is related to the damping of thermally excited spin

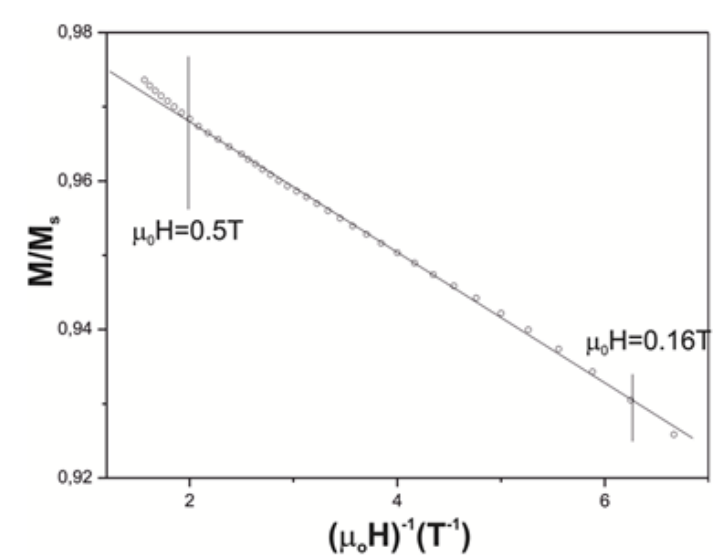

Fig. 8. Magnetization curve in function of $\left(\mu_{0} \mathrm{H}\right)^{-1}$ for the investigated alloy

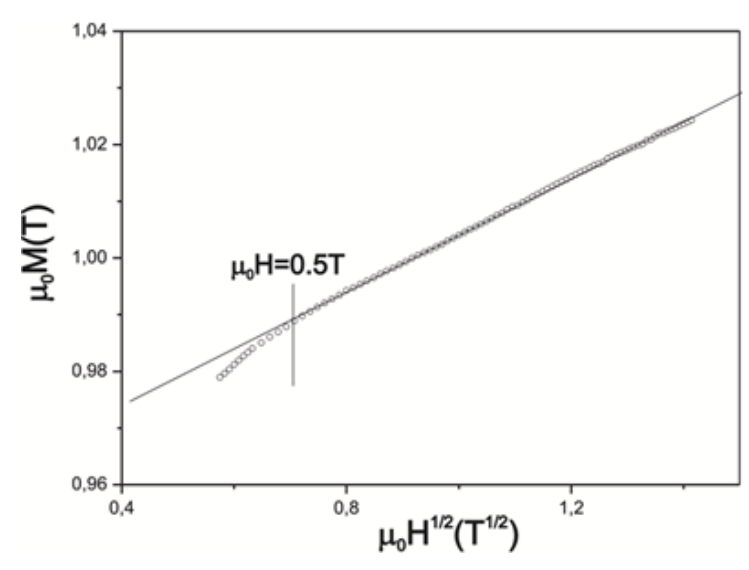

Fig. 9. Magnetization curve in function of $\left(\mu_{0} \mathrm{H}\right)^{1 / 2}$ for the investigated alloy

waves by the magnetic field. This phenomenon describes the so-called Holstein-Primakoff paraproces [46] (fig. 9).

\section{Conclusion}

From the results of this research we can conclude the following:

-Using the method of injecting a liquid alloy into a copper water-cooled mold it is possible to make an amorphous alloy sample $\mathrm{Fe}_{55} \mathrm{CO}_{15} \mathrm{~W}_{2} \mathrm{Y} \mathrm{B}_{20}$ in the form of $1 \mathrm{~mm}$ rods.

-The produced material has a high Curie temperature.

-The total core losses for the tested material is low.

-Lack of crystalline structure favors the minimization of magnetostriction.

-The magnetizing process in the region known as the approach to ferromagnetic saturation is dominated by twodimensional defects called pseudodislocation dipoles.

-For the conducted scope of research, no anomalous behavior was observed for the material produced.

\section{References}

1.INOUE A, GOOK J. S., Mater. Trans. JIM 36, 1995, p. 1180.

2.INOUE A., KATSUYA A., Mater. Trans. JIM 37, 1996, p. 1332.

3.INOUE A., ZHANG T., ITOI T, TAKEUCHI A., Mater. Trans. JIM 38, 1997, p. 359.

4.INOUE A., KOSHIBA H., ITOI T., MAKINO A., Appl. Phys. Lett. 73, 1998, p. 744.

5.NABIALEK M., Arch. Metall. Mater.61, 2016, p. 445.

6.NABIALEK M., J. Alloys Comp. 642, 2015, p. 98.

7.INOUE A., Mater. Sci. Fundations 6, 1998, p. 1.

8.PIETRUSIEWICZ P., NABIALEK M., Acta Phys. Pol. A, 131 nr 4, 2017, p. 678.

9.GONDRO J., J. Magn. Magn. Mater., 432, 2017, p. 501.

10.NABIALEK M., J. Alloys Comp., 642, 2015, p. 98.

11.BLOCH K., J. Magn. Magn. Mater., 390, 2015, p. 118.

12.THOMAS T., GIBBS M. R. J, J. Magn. Magn. Mater., 103, 1992, p.97. 13.PIETRUSIEWICZ P., NABIALEK M., DOSPIAL M., GRUSZKA K., BLOCH K., GONDRO J., BRGIEL P., SZOTA M., STRADOMSKI Z., J. Alloys Comp., $615 \mathrm{nr}$ S1, 2015, p. S67.

14.HASIAK M., SOBCZYK K., ZBROSZCZYK J., CIURZYNSKA W., OLSZEW SKI J ., NABIALEK M., KALETA J ., EWIERCZEK J ., LUKIEW SKA A., IEEE Trans. Magn. 11, 2008, p.3879.

15.BRAND A., Nuclear Instruments and Methods in Physics Research Section B, B28, 1987, p. 398 .

16.OLSZEWSKI J., ZBROSZCZYK J., SOBCZYK K., CIURZYNSKA W., BR ¥GIEL P., NABIALEK M., SWIERCZEK J.,. HASIAK M, LUKIEWSKA A., Acta. Phys. Pol. A 114, 2008, p. 1659.

17.INOUE, A., ZHANG, T., MASUMOTO T., Mater. Trans. JIM 31, 1990, p. 177.

18.BLOCH, K., NABIALEK, M., Acta. Phys. Pol. A, 127, 2015, p. 442.

19.INOUE A., Mat. Sci. Eng. A, A226-228, 1997, p. 357. 
20.LIU, T., RAY, S.C., TSAI, H.M., PAO, C.W., LING, D.C., PONG, W.F., CHIOU, J.W., TSAI, M.-H., JANG, L.Y., PI, T.W., LEE, J.F., LIN, C.Y., CHIN, T.S., J. Phys. Condens. Matter 20, 2008, 465105.

21.J. WANG, R. LI, N. HUA, L. HUANG, T. ZHANG, Scr. Mater. 65, 2011, p. 536.

22.MAKINO, A., KUBOTA, T., CHANG, C., MAKABE, M., INOUE, A., J. Magn. Magn. Mater. 320, 2008, p. 2499.

23.JUNG H.Y, YI, S., Intermetallics 18, 2010, p. 1936.

24.NABIALEK, M., Arch. Metall. Mater.61, 2016, p. 445.

25.NABIALEK, M., J. Alloys Comp. 642, 2015, p. 98.

26.GONDRO, J., J. Magn. Magn. Mater. 432, 2017, p. 501.

27.MASOOD, A., STROM, V., BELOVA, L., RAO, K.V., AGREN, J., J. Appl.

Phys. 113, 2013, 013505.

28.STOICA, M., HAJ LAOUI, K., LEMOULEC, A., YAVARI, A.R., Philos. Mag. Lett. 86, 2006, p. 267.

29.LU, Z.P, LIU, C.T., THOMPSON, J.R., PORTER W.D, Rev. Letter.Vol., 92, 2004, p. 245503.

30.LI, H.X., WANG, S.L., YI, S., JIAO, Z.B., WU, Y., LU, Z.P., J. Magn. Magn. Mater. 321, 2009, p.2833.

31.H.Y. JUNG, M. STOICA, S. YI, D.H. KIM, J. ECKERT, J. Magn. Magn. Mater. 364, 2014, p. 80.

32.MAKINO, A., KUBOTA T., CHANG C., MAKABE, M., A. INOUE, J. Magn. Magn. Mater. 320, 2008, p. 2499.

33.H.Y. JUNG, S. YI, Intermetallics 18, 2010, p. 1936.

34.NABIALEK M., Arch. Metall. Mater.61, 2016, p. 445.

35.KRONMÜLLER H., J. Appl. Phys. 52, 1981, p.1859.

36.IONESCU, D., MATASARU, D., RADU, V., University Politehnica Of Bucharest Scientific Bulletin-Series A-Applied Mathematics And Physics, 75, no. 4, 2013, p. 265.
37.SANDU, A.V., CODDET, C., BEJ INARIU, C., J ournal of Optoelectronics and Advanced Materials, 14, no. 7-8, 2012, p. 699.

38.BALTATU, S., VIZUREANU, P., MARECI, D., BURTAN, L.C., CHIRUTA, C., TRINCA, L.C., Materials and Corrosion-Werkstoffe und Korrosion, 67, no. 12, 2016, p. 1314.

39.SANDU, A.V., CIOMAGA, A., NEMTOI, G., BEJ INARIU, C., SANDU, I., J ournal of Optoelectronics and Advanced Materials, 14, no. 7-8, 2012, p. 704.

40.ACHITEI, D.C., VIZUREANU, P., DANA, D., CIMPOESU, N., Metalurgia International, 18, special issue 2, 2013, p. 104.

41.BALTATU, M.S., VIZUREANU, P., CIMPOESU, R., ABDULLAH, M.M.A., SANDU, A.V., Rev. Chim. (Bucharest), 67, no 10, 2016, p. 2100.

42.DANDU-BIBIRE, L., BORSOS, Z., MATASARU, D., CASIAN-BOTEZ, I., NICULESCU, A., AGOP, M., University Politehnica Of Bucharest Scientific Bulletin-Series A-Applied Mathematics And Physics, 73, no. 2, 2011, p. 175.

43.DOROFTEI, B., MAMBET, C., ZLEI, M., PLOS ONE, 10, no. 4, 2015, Article Number: e0125216

44.DOLOCA, A., TANCULESCU, O., TRANDAFIR, L., CIONGRADI, I., STOLERIU, S., MOCANU, R., IFTENI, G., Materiale Plastice, 53, no. 3, 2016, p. 370-374

45.TANTARU, G., APOSTU, M., Rev. Chim (Bucharest), 61, no. 7, 2010, p. 632.

46.HOLSTEIN T., PRIMAKOFF H, Phys. Rev. 58, 1940, p. 1098.

$\overline{\text { Manuscript received:10.10.2018 }}$ 